This item was submitted to Loughborough's Research Repository by the author.

Items in Figshare are protected by copyright, with all rights reserved, unless otherwise indicated.

\title{
Tools of legitimacy: The case of the Petrobras Corporate Blog [Review of article].
}

PLEASE CITE THE PUBLISHED VERSION

http://dx.doi.org/10.1080/0969160X.2016.1197624

PUBLISHER

(c) Taylor \& Francis

\section{VERSION}

AM (Accepted Manuscript)

\section{PUBLISHER STATEMENT}

This work is made available according to the conditions of the Creative Commons Attribution-NonCommercialNoDerivatives 4.0 International (CC BY-NC-ND 4.0) licence. Full details of this licence are available at: https://creativecommons.org/licenses/by-nc-nd/4.0/

\section{LICENCE}

CC BY-NC-ND 4.0

\section{REPOSITORY RECORD}

Vourvachis, Petros. 2019. "Tools of Legitimacy: The Case of the Petrobras Corporate Blog [review of Article].". figshare. https://hdl.handle.net/2134/21814. 


\section{Tools of Legitimacy: The Case of the Petrobras Corporate Blog}

M. Barros

Organization Studies 2014, 35 (8), pp. 1211-1230

This paper adds to the literature that explores corporate interactions with media, by focusing on how organisations use new social technologies as tools, in the discursive struggle over legitimacy. More particularly, the paper investigates one such struggle between the corporate blog published by Brazil's state-owned company Petrobras, and local newspapers. The investigation has focused in the first six months of the development of the company's blog and data considered include 222 blog entries (along with their comments) as well as 248 press articles from regional and national newspapers and magazines. Critical discourse analysis is then employed, building on Fairclough's notion of intertextuality (i.e. the way a text draws on other texts and discourses) and with particular reference to hypertexts (i.e. web texts which contain links to other texts, hence the author's developed notion of 'hyper-intertextuality').

The reader approaches papers looking at new social media with interest, as particularly social and environmental reporting research has long been dominated by studies exploring the legitimation purpose of annual reports, and more recently of stand-alone reports, whereas research on social media, such as blogs or social networks remains scant. Research on corporate interactions with media also usually focuses on annual reports or press releases as sources of corporate disclosure and on newspaper articles as media sources, and has so far typically ignored new interactive technologies. These however can greatly influence the dynamics and shape of organisational discourse, as they could constitute a potentially important 'third player', one that more directly reflects the opinions and interests of general public and can thus potentially contribute towards edemocracy. As the author finds however, it is particularly difficult to reliably capture and study these opinions: e.g. in the case of blog comments it was difficult to distinguish between genuine comments made by the general public from comments made from inside the corporation, aiming to deceive stakeholders and boost image.

Findings suggest that the blogs "serve as online public relations tools" (p. 1215) and that Petrobras "made use of social media to publicly challenge negative press reporting" (p. 1216). Blogs therefore appear to have a legitimation purpose not very different to that of e.g. annual/stand-alone reports or press releases. Future research could more closely look at the differences in reporting as well as underlying motivations behind using similar communication forms that directly reach stakeholders (such as press releases, blogs as well as networking media such as Twitter and Facebook). Research could particularly focus on stakeholder interaction through these media: as Rinaldi et al. (2014, p. 104) have stressed, "There is... considerable potential for greater academic research in this area to help organizations develop more sophisticated stakeholder engagement and dialogue processes in their journeys towards more effective sustainable development practices, including sustainability accounting and accountability." Finally, and whilst the notable increased research focus on hypertexts (containing links to other texts) is undoubtedly welcome, hypotexts (i.e. earlier texts which serve as the source of subsequent pieces of literature) also deserve our attention. How does the choice of an earlier text influence arguments in later texts (particularly when the earlier writers' intentions are misrepresented as it is often the case in the sustainability domain) would be particularly worthwhile to be looked at, both at corporate and regulatory levels.

Reference

Rinaldi, L., Unerman, J. and Tilt, C. (2014), "The role of stakeholder engagement and dialogue within the sustainability accounting and reporting processes", in J. Bebbington, J. Unerman and B. O'Dwyer (Eds.), Sustainability Accounting and Accountability, $2^{\text {nd }}$ Ed., London: Routledge, pp. 86-107. 